Corrigendum

\title{
Corrigendum to "Synthesis and Characterization of New Palladium(II) Thiosemicarbazone Complexes and Their Cytotoxic Activity against Various Human Tumor Cell Lines"
}

\author{
Wilfredo Hernández, ${ }^{1}$ Juan Paz, ${ }^{1}$ Fernando Carrasco, ${ }^{2}$ \\ Abraham Vaisberg, ${ }^{3}$ Evgenia Spodine, ${ }^{4}$ Jorge Manzur, ${ }^{5}$ Lothar Hennig, ${ }^{6}$ \\ Joachim Sieler, ${ }^{6}$ Steffen Blaurock, ${ }^{6}$ and Lothar Beyer ${ }^{6}$ \\ ${ }^{1}$ Facultad de Ingeniería Industrial, Universidad de Lima, Avenida Javier Prado Este Cuadra 46, Urbanización Monterrico, \\ Lima 33, Peru \\ ${ }^{2}$ Facultad de Ciencias Naturales y Matemática, Universidad Nacional Federico Villarreal, Jr. Río Chepén s/n, El Agustino, Lima, Peru \\ ${ }^{3}$ Laboratorio de Investigación y Desarrollo, Facultad de Ciencias y Filosofía, Universidad Peruana Cayetano Heredia, \\ Avenida Honorio Delgado 430, Urbanización Ingeniería-San Martin de Porras, Lima 31, Peru \\ ${ }^{4}$ Facultad de Ciencias Químicas y Farmacéuticas, Universidad de Chile, CEDENNA, Olivos 1007, Casilla 233, Independencia, \\ 8330492 Santiago, Chile \\ ${ }^{5}$ Facultad de Ciencias Físicas y Matemáticas, Universidad de Chile, CEDENNA, 8370448 Santiago, Chile \\ ${ }^{6}$ Fakultät für Chemie und Mineralogie, Universität Leipzig, Johannisallee 29, 04103 Leipzig, Germany
}

Correspondence should be addressed to Wilfredo Hernández; whernandez79@yahoo.es

Received 16 March 2015; Accepted 16 March 2015

Copyright (C) 2015 Wilfredo Hernández et al. This is an open access article distributed under the Creative Commons Attribution License, which permits unrestricted use, distribution, and reproduction in any medium, provided the original work is properly cited.

In the references of the published paper entitled "Synthesis and Characterization of New Palladium(II) Thiosemicarbazone Complexes and Their Cytotoxic Activity against Various Human Tumor Cell Lines," we mistakenly wrote the names of the authors in reference [5], so the corrected reference [5] is as follows: I. Kizilcikli, Y. D. Kurt, B. Akkurt et al., "Antimicrobial activity of a series of thiosemicarbazones and their $\mathrm{Zn}^{\mathrm{II}}$ and $\mathrm{Pd}^{\mathrm{II}}$ Complexes," Folia Microbiologica, vol. 52, pp. 15-25, 2007. 

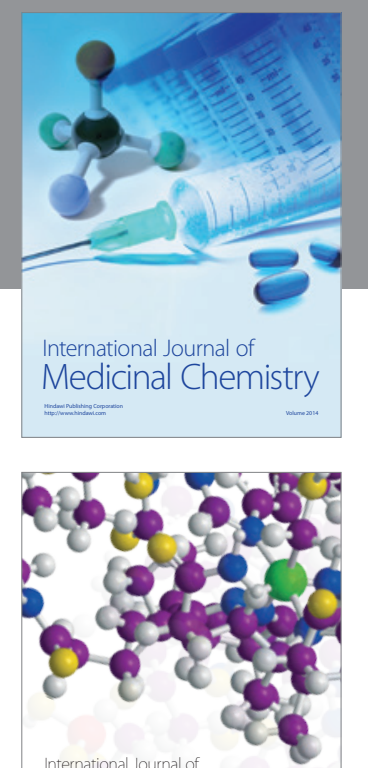

\section{Carbohydrate} Chemistry

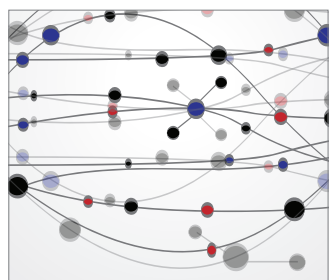

The Scientific World Journal
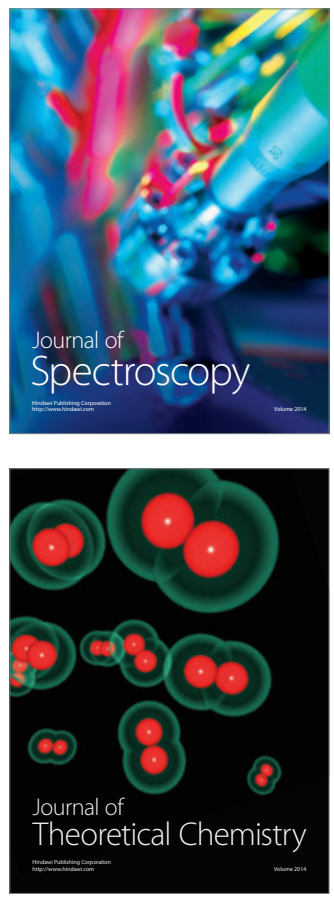
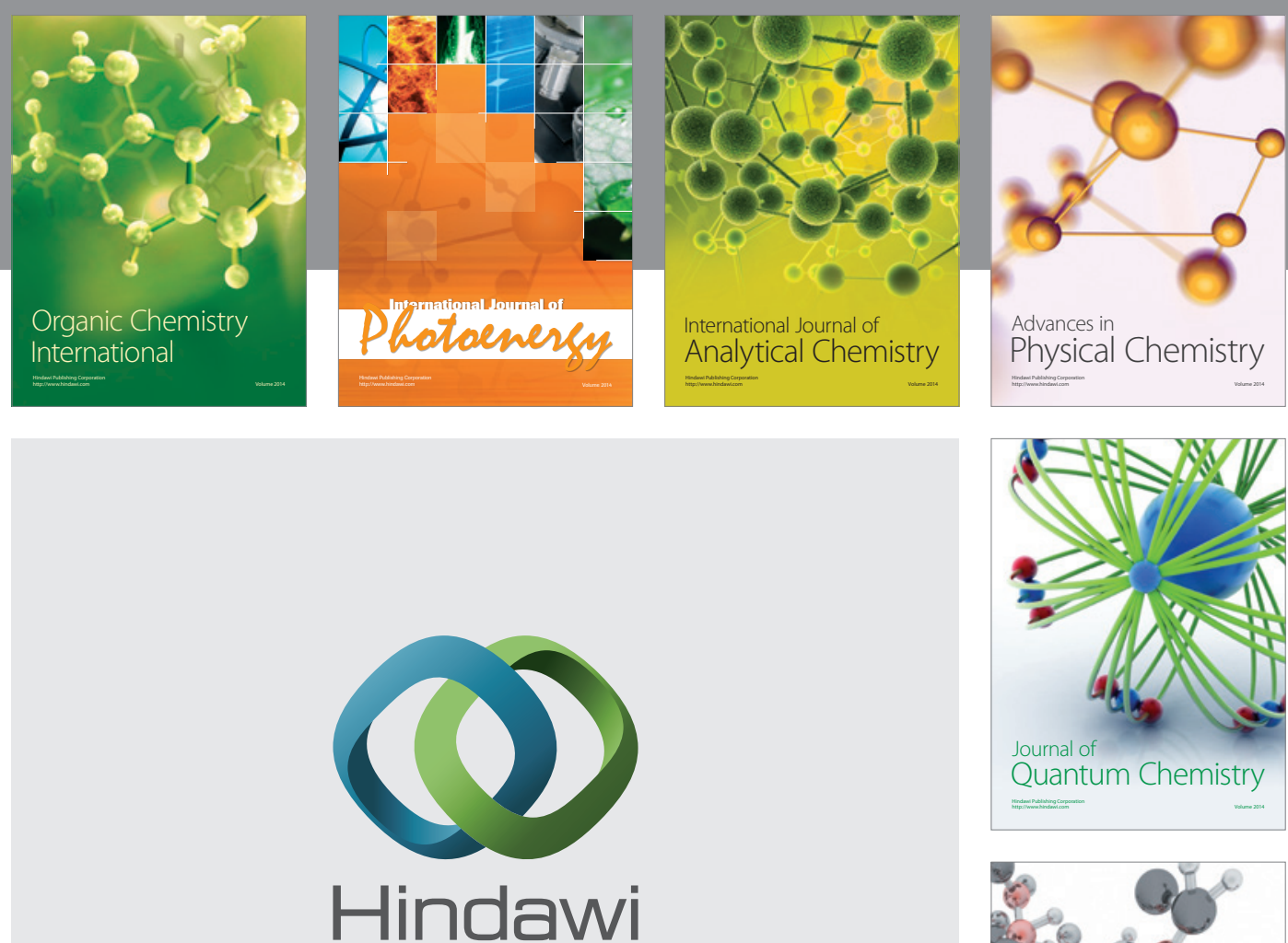

Submit your manuscripts at

http://www.hindawi.com

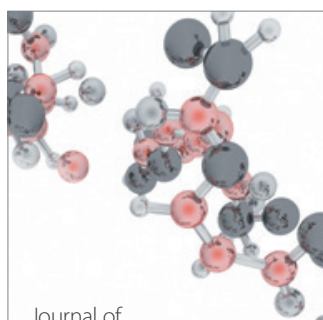

Analytical Methods

in Chemistry

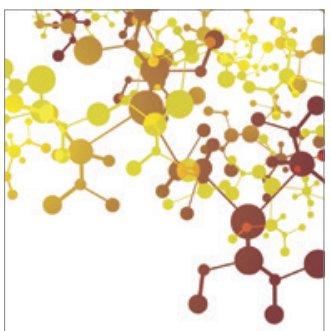

Journal of

Applied Chemistry

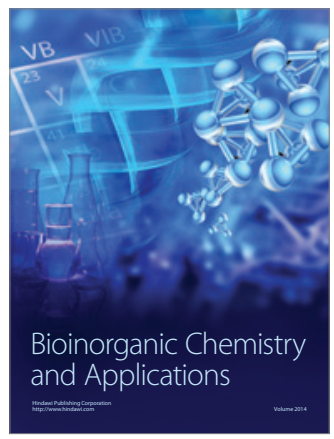

Inorganic Chemistry
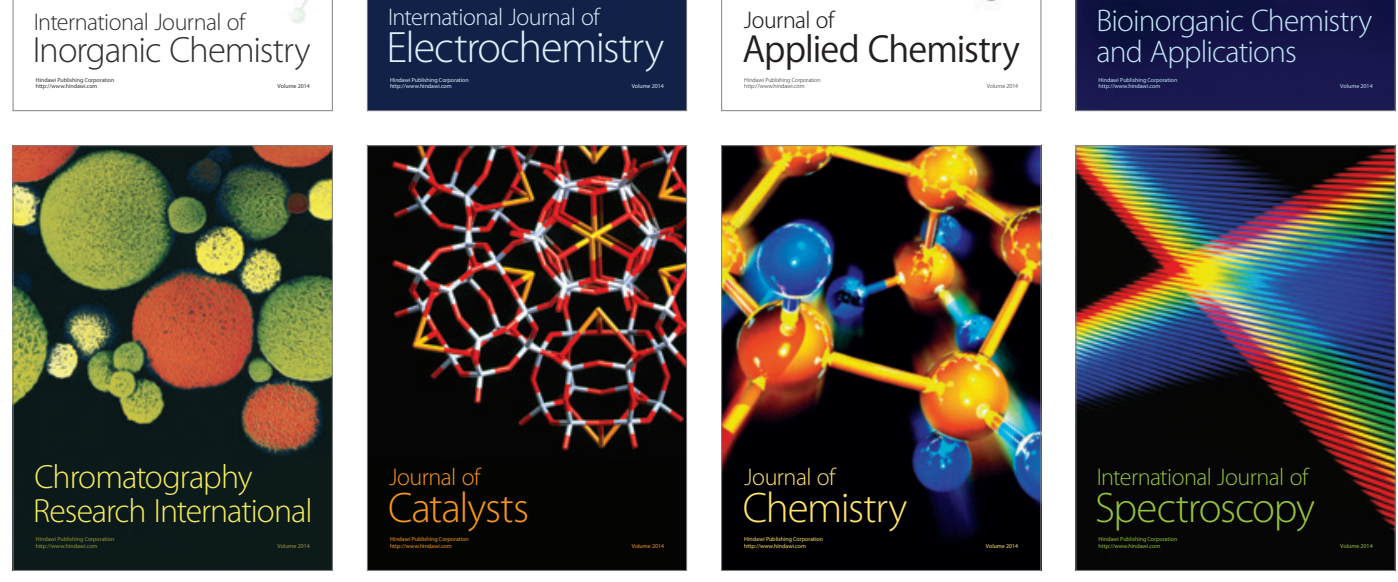